\title{
High-Performance Complementary Electrochromic Device Based on Iridium Oxide as a Counter Electrode
}

\author{
Tien-Fu Ko ${ }^{1,2}$, Po-Wen Chen ${ }^{2, *}$, Kuan-Ming Li ${ }^{1} * \mathbb{C}$, Hong-Tsu Young ${ }^{1}$, Chen-Te Chang ${ }^{2}$ and Sheng-Chuan Hsu ${ }^{2}$ \\ 1 Department of Mechanical Engineering, National Taiwan University, Taipei City 10617, Taiwan; \\ chahlesko@iner.gov.tw (T.-F.K.); hyoung@ntu.edu.tw (H.-T.Y.) \\ 2 Division of Physics, Institute of Nuclear Energy Research, Taoyuan City 32546, Taiwan; \\ ctechang@iner.gov.tw (C.-T.C.); g923319@iner.gov.tw (S.-C.H.) \\ * Correspondence: powen@iner.gov.tw (P.-W.C.); kmli@ntu.edu.tw (K.-M.L.); \\ Tel.: +886-3-4711-400 (ext. 7483) (P.-W.C.); +886-2-336-644-82 (K.-M.L.)
}

Citation: Ko, T.-F.; Chen, P.-W.; Li, K.-M.; Young, H.-T.; Chang, C.-T.; Hsu, S.-C. High-Performance Complementary Electrochromic Device Based on Iridium Oxide as a Counter Electrode. Materials 2021, 14 , 1591. https://doi.org/10.3390/ ma14071591

Academic Editor: Dimitra Vernardou

Received: 14 February 2021

Accepted: 18 March 2021

Published: 24 March 2021

Publisher's Note: MDPI stays neutral with regard to jurisdictional claims in published maps and institutional affiliations.

\begin{abstract}
In complementary electrochromic devices (ECDs), nickel oxide (NiO) is generally used as a counter electrode material for enhancing the coloration efficiency. However, an $\mathrm{NiO}$ film as a counter electrode in ECDs is susceptible to degradation upon prolonged electrochemical cycling, which leads to an insufficient device lifetime. In this study, a type of counter electrode iridium oxide $\left(\mathrm{IrO}_{2}\right)$ layer was fabricated using vacuum cathodic arc plasma (CAP). We focused on the comparison of $\mathrm{IrO}_{2}$ and $\mathrm{NiO}$ deposited on a $5 \times 5 \mathrm{~cm}^{2}$ indium tin oxide (ITO) glass substrate with various $\mathrm{Ar} / \mathrm{O}_{2}$ gas-flow ratios $(1 / 2,1 / 2.5$, and $1 / 3)$ in series. The optical performance of $\mathrm{IrO}_{2}-\mathrm{ECD}$ (glass $/ \mathrm{ITO} / \mathrm{WO}_{3} /$ liquid electrolyte $/ \mathrm{IrO}_{2} / \mathrm{ITO} /$ glass) was determined by optical transmittance modulation; $\Delta \mathrm{T}=50 \%$ (from $\mathrm{T}_{\text {bleaching }}(75 \%)$ to $\left.\mathrm{T}_{\text {coloring }}(25 \%)\right)$ at $633 \mathrm{~nm}$ was higher than that of $\mathrm{NiO}-\mathrm{ECD}$ (ITO/NiO/liquid electrolyte $\left./ \mathrm{WO}_{3} / \mathrm{ITO}\right)(\Delta \mathrm{T}=32 \%)$. Apart from this, the ECD device demonstrated a fast coloring time of $4.8 \mathrm{~s}$, a bleaching time of $1.5 \mathrm{~s}$, and good cycling durability, which remained at $50 \%$ transmittance modulation even after 1000 cycles. The fast time was associated with the $\mathrm{IrO}_{2}$ electrode and provided higher diffusion coefficients and a filamentary shape as an interface that facilitated the transfer of the $\mathrm{Li}$ ions into/out of the interface electrodes and the electrolyte. In our result of $\mathrm{IrO}_{2}$-ECD analyses, the higher optical transmittance modulation was useful for promoting electrochromic application to a cycle durability test as an alternative to NiO-ECD.
\end{abstract}

Keywords: iridium oxide $\left(\mathrm{IrO}_{2}\right)$ film; nickel oxide (NiO) film; electrochromic device (ECD); cathodic arc plasma (CAP)

\section{Introduction}

Electrochromic devices (ECDs) have attracted considerable attention because they have tremendously promising applications in energy-saving smart windows that can enhance the optical properties and durability reversibly upon the application of a Direct Current (DC) voltage [1,2]. Electrochromic (EC) materials applied on smart windows can easily dominate the indoor illumination and effectively decrease the air-condition loading of buildings [3,4]. Furthermore, ECDs can save renewable energy and cause a persistent reversible color change upon the application of a small voltage [3,4] to reduce the energy consumption significantly; therefore, they are an extraordinary material providing some unique advantages such as larger optical modulation and better cyclic stability against sunlight exposure, for smart windows in a green building environment $[5,6]$. In general, ECD consists of a five-layer structure such as TCO/EC/IC/CE/TCO layers, where TCO, IC, and $\mathrm{CE}$ are transparent conducting oxide, ion conducting layer, and counter electrode, respectively [7-9]. In recent years, electrochromic materials have attracted considerable research interest in numerous metal-oxides, including molybdenum trioxide $\left(\mathrm{MoO}_{3}\right)$, vanadium oxide $\left(\mathrm{V}_{2} \mathrm{O}_{5}\right)$, niobium oxide $\left(\mathrm{Nb}_{2} \mathrm{O}_{5}\right)$, and titanium dioxide $\left(\mathrm{TiO}_{2}\right)[9,10]$. In addition to the oxides, conducting polymers are also widely studied in electrochromic devices [11,12]. 
However, typically, complementary electrochromic devices include anodic and cathodic electrodes in a multi-layer. Tungsten oxide $\left(\mathrm{WO}_{3}\right)$ film is the most commonly used electrode material and is complementary to an anodic layer of $\mathrm{NiO}$ or another extraordinary material such as $\mathrm{IrO}_{2}$ [13-15]. Electrochromic $\mathrm{IrO}_{2}$ and $\mathrm{NiO}$ films have been manufactured by diverse procedures such as sputtering [16,17], pulsed laser system [18], cathodic electrodeposition [19], chemical vapor deposition [20,21], thermal evaporation [22-24], and sol-gel [25-27].

Here, a type of counter electrode iridium oxide $\left(\mathrm{IrO}_{2}\right)$ layer was fabricated using vacuum cathodic arc plasma (CAP). We compared two anodic coloration material of $\mathrm{IrO}_{2}$ and $\mathrm{NiO}$ films $[13,14]$ which showed $\mathrm{IrO}_{2}$ films were better to enhance electrochromic properties than $\mathrm{NiO}$. Cathodic arc plasm (CAP) fabricated procedure has been widely used in several types of films owing to the outstanding features of the arc plasma fabricated from cathode spots. In this method, the macro-particles (MPs) are released on account of the severe plasma-liquid pool influence on the cathode spots, and MPs sticking to the films make worse the properties of thin films. The infamous macro particle situation is the key reason why CAP system is not commonly applied in high-tech field. We implemented two ways to improve the quality of materials. One is to reduce macro-particles when arc discharge from a random (insufficient and outer magnetic field) to an arc (at axial magnetic field) showed that immediately improve the quality of nitride coating [28]. The result showed that less macro particles are thrown out using high horizontal magnetic field and increasing clear spot velocity [29]; another is by means of Theorton deposition [30], the composition of loose-packing structure at high working pressure condition. Arc plasms can be controlled in high pressure, and the structure may appear self-organized and lessen macro particle size [31]. Recently, researchers have investigated more study in monolithic coatings than higher-performing multilayers. The formation of electrode structure is controlled by the flow of argon (for insertion) and oxygen (reaction) [8]. In the recent years, $\mathrm{P}$. W. Chen et al. [32] investigated in vacuum cathodic arc plasma (CAP) to fabricate all solid-state electrochromic devices (ECDs) with tantalum oxide $\left(\mathrm{Ta}_{2} \mathrm{O}_{5}\right)$ as ion conductor layer. It emphasized on manufacturing $\mathrm{Ta}_{2} \mathrm{O}_{5}$ film by CAP with various gas ratios of oxygen and argon. K. Li et al. [33] suggested that indium-zinc-tin oxide (IZTO) films make use of the controlling powers of DC magnetron sputtering to improve the surface properties of ITO as a transparent electrode. We have manufactured ECD composing of a $\mathrm{WO}_{3}$ electrode film on IZTO/ITO/glass and a counter-electrode (Pt mesh) using $0.2 \mathrm{M}$ $\mathrm{LiClO}_{4} / \mathrm{PC}$ solution. P. W. Chen et al. [8] used CAP deposition to make the porous surface structure of $\mathrm{WO}_{3} / \mathrm{NiO}$ films to upgrade the electrochromic performance. They found that the thickness of $\mathrm{WO}_{3}$ layers is an essential factor of ECDs for optical and electrochemical properties. However, the $\mathrm{NiO}$ film used as a counter electrode in ECDs is more susceptible to degrade upon prolonged electrochemical cycling which leads to insufficient device lifetime than $\mathrm{IrO}_{2}$ film.

In this study, we used a CAP technology to deposit $\mathrm{IrO}_{2}$ films provided porous surface structure to elevate electrochromic properties and promote switching speeds. The aim of this work was to compare between $\mathrm{IrO}_{2}$ and $\mathrm{NiO}$ films; however, a systematic study of the effect of the Ar/ $\mathrm{O}_{2}$ mixing ratio by means of CAP is lacking. This fabricated technology is exclusive for high deposition rates with a low-cost method and can be used to fabricate diverse transition metal-oxides having nanostructures with a morphological phenomenon. We focused on the influence of various $\mathrm{Ar} / \mathrm{O}_{2}$ gas-flow ratios with an $\mathrm{IrO}_{2}$ electrode as compared to $\mathrm{NiO}$ on the diffusion behavior of ion insertion/extraction, material structure, surface morphology, transmittance optical modulation, and durability test.

\section{Materials and Methods}

\subsection{Preparation of Transparent and Electrochromic Electrodes and Electrolyte Materials}

In this study, we used of method of CAP deposition technology as an alternative to sputtering in order to achieve high deposition rates at a low cost of producing EC films based on $\mathrm{NiO}$ and $\mathrm{IrO}_{2}$ electrodes for ECD applications. We prepared a series of $\mathrm{IrO}_{2}$ 
(Sample 1-3) and $\mathrm{NiO}$ films (Sample 4-6) under increasing $\mathrm{Ar} / \mathrm{O}_{2}$ gas-flow ratios (1/2, $1 / 2.5$, and $1 / 3$ ) as anodic layers, which were deposited on a $5 \times 5 \mathrm{~cm}^{2}$ indium tin oxide (ITO) glass substrate with a resistance of $6 \Omega / \mathrm{cm}^{2}$. The deposition process is presented in Table 1. Prior to the deposition of each electrochromic layer, the ITO-coated glasses were cleaned ultrasonically with ethyl alcohol and deionized water for $15 \mathrm{~min}$ to remove contaminants. Both the $\mathrm{IrO}_{2}$ and $\mathrm{NiO}$ electrodes were implemented via cathodic arc plasma (CAP) by using a pure metallic iridium (Ir) target (99.95\%) and nickel (Ni) target (99.95\%) with a diameter of $76 \mathrm{~mm}$, respectively, in the vacuum chamber. Moreover, $\mathrm{WO}_{3}$ as the cathodic layer using a tungsten (W) target $(99.95 \%)$ was fabricated, as listed in Table 2 by using the CAP technology. For the electrodes to ensure the lithium $\left(\mathrm{Li}^{+}\right)$ion transport, we were carried out a liquid electrolyte system containing lithium perchlorate $\left(\mathrm{LiClO}_{4}\right)$ and propylene carbonate $\left(\mathrm{PC}, \mathrm{C}_{4} \mathrm{H}_{6} \mathrm{O}_{3}\right.$ ) at a weight ratio of 0.1325 [4]. The complementary electrochromic devices (ECDs) consisted of five superimposed layers with an ITO (300 $\mathrm{nm}) / \mathrm{IrO}_{2}(100 \mathrm{~nm}) / \mathrm{LiClO}_{4}-\mathrm{PC}(100 \mathrm{um}) / \mathrm{WO}_{3}(100 \mathrm{~nm}) / \mathrm{ITO}(300 \mathrm{~nm})$ structure and fabricated by deposited system respectively in Figure 1.

Table 1. Deposition parameters of $\mathrm{IrO}_{2}$ and $\mathrm{NiO}$ electrode films.

\begin{tabular}{cccccccc}
\hline No. & Electrode & $\begin{array}{c}\mathrm{Ar} / \mathrm{O}_{\mathbf{2}} \\
(\mathrm{Ar}=\mathbf{2 0} \\
\mathbf{s c c m})\end{array}$ & $\begin{array}{c}\text { W.P. } \\
\text { (Torr) }\end{array}$ & $\begin{array}{c}\text { DC } \\
\text { Power } \\
\text { (W) }\end{array}$ & $\begin{array}{c}\text { Deposition } \\
\text { Temp } \\
\left({ }^{\circ} \mathbf{C}\right)\end{array}$ & $\begin{array}{c}\text { Deposition } \\
\text { Time } \\
\text { (s) }\end{array}$ & $\begin{array}{c}\text { Thickness } \\
(\mathbf{n m})\end{array}$ \\
\hline Sample 1 & $\mathrm{IrO}_{2}$ & $1 / 2$ & $1.2 \times 10^{-3}$ & 1250 & 100 & 40 & 100 \\
Sample 2 & $\mathrm{IrO}_{2}$ & $1 / 2.5$ & $1.7 \times 10^{-3}$ & 1250 & 100 & 40 & 100 \\
Sample 3 & $\mathrm{IrO}_{2}$ & $1 / 3$ & $1.9 \times 10^{-3}$ & 1250 & 100 & 40 & 100 \\
Sample 4 & $\mathrm{NiO}$ & $1 / 2$ & $1.2 \times 10^{-3}$ & 1250 & 100 & 100 & 100 \\
Sample 5 & $\mathrm{NiO}$ & $1 / 2.5$ & $1.7 \times 10^{-3}$ & 1250 & 100 & 100 & 100 \\
Sample 6 & $\mathrm{NiO}$ & $1 / 3$ & $1.9 \times 10^{-3}$ & 1250 & 100 & 100 & 100 \\
\hline
\end{tabular}

Table 2. Deposition parameters of transparent ITO glass and $\mathrm{WO}_{3}$ electrode film.

\begin{tabular}{cccccccc}
\hline Target & $\begin{array}{c}\text { W.P. } \\
\text { (Torr) }\end{array}$ & $\begin{array}{c}\text { Ar/O } \\
(\mathbf{s c c m})\end{array}$ & $\begin{array}{c}\text { DC } \\
\text { power } \\
(\mathbf{W})\end{array}$ & $\begin{array}{c}\text { Deposition } \\
\text { Time } \\
(\mathbf{m i n})\end{array}$ & $\begin{array}{c}\text { Deposition } \\
\text { Rate } \\
(\mathbf{n m} / \mathbf{m i n})\end{array}$ & $\begin{array}{c}\text { Deposition } \\
\text { Temp } \\
{ }^{\circ} \mathbf{C}\end{array}$ & $\begin{array}{c}\text { Thickness } \\
(\mathbf{n m})\end{array}$ \\
\hline ITO & $3 \times 10^{-3}$ & $\begin{array}{c}1 / 3 \\
(\mathrm{Ar}=100) \\
1 / 3\end{array}$ & 500 & 60 & 5 & 200 & 300 \\
W Metal & $8 \times 10^{-3}$ & $\begin{array}{c}1 / 3 \\
(\mathrm{Ar}=100)\end{array}$ & 1500 & 15 & 13.3 & 50 & 200 \\
\hline
\end{tabular}

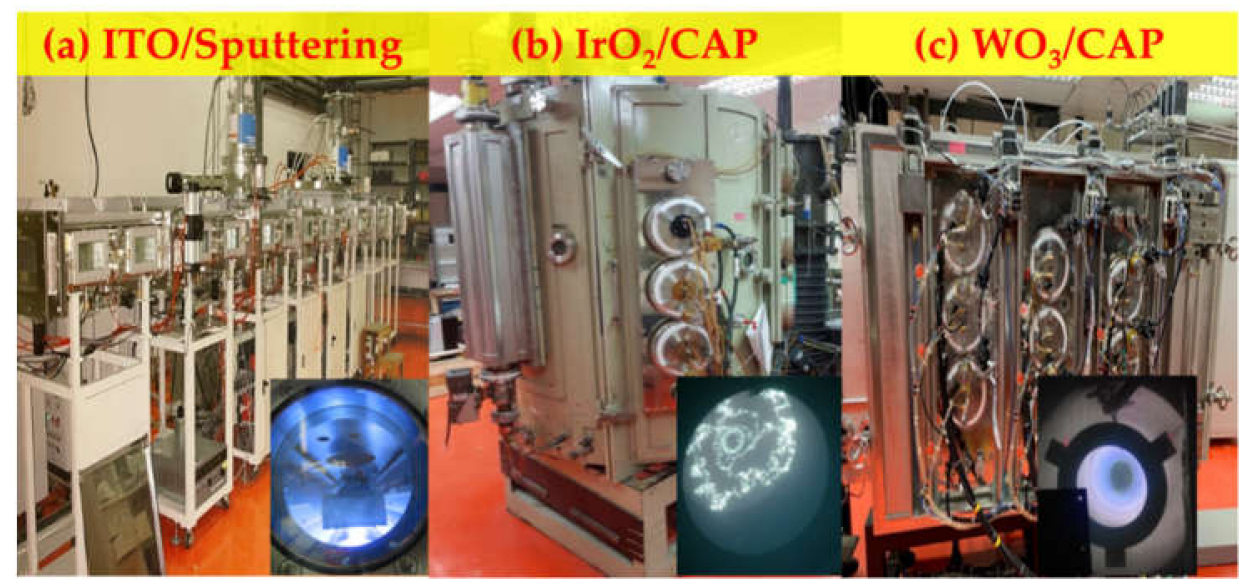

Figure 1. Complementary electrochromic device deposited system (a) indium tin oxide (ITO), (b) $\mathrm{IrO}_{2}$ electrode, and (c) $\mathrm{WO}_{3}$ electrode.

\subsection{Measurements and Characterizations}

The electrochemical properties of the electrochromic electrodes were measured using cycle voltammetry (CV) (model PGSTAT30, Autolab, Utrecht, The Netherlands) in a three- 
compartment system containing the abovementioned electrodes as the working electrodes $\left(\mathrm{IrO}_{2} / \mathrm{ITO} /\right.$ glass and $\mathrm{NiO} / \mathrm{ITO} /$ glass$)$ and $\mathrm{Ag} / \mathrm{AgCl}$ as the reference electrodes, and $\mathrm{Pt}$ foil as the counter electrodes. Sample 1-6 carried out electrochemical cycles in the 0.5-M $\mathrm{LiClO}_{4}-\mathrm{PC}$ solution at $-0.5 \mathrm{~V}$ to $2.0 \mathrm{~V}$ and a potential sweep rate of $100 \mathrm{mV} / \mathrm{s}$. The optical transmittance spectra of the colored and the bleached states were obtained using an ultraviolet-visible (UV-Vis) spectrophotometer (model DH-2000-BAL, Ocean Optics, Dunedin, FL, USA) in a wavelength range from $300 \mathrm{~nm}$ to $1000 \mathrm{~nm}$. The crystalline structure was characterized by a high-resolution X-ray diffractometer (HRXRD, Model D8, Bruker AXS, Billerica, MA, USA) equipped with a $\mathrm{CuK} \alpha(\lambda=0.154 \mathrm{~nm})$ radiation source over a $2 \theta$ scan region of $20^{\circ}$ to $70^{\circ}$. It is provided with the essential accuracy and precision to measure the broadening and the relative peak. The surface morphological properties were examined with a field emission scanning electron microscope (FE-SEM) (Model S4800, Hitachi, Tokyo, Japan) operated at $15 \mathrm{kV}$.

\section{Results and Discussion}

\section{1. $\mathrm{IrO}_{2} / \mathrm{ITO}$ and NiO/ITO Films: Ionic Diffusion}

In this work, we utilized the cyclic voltammetry (CV) method and the Randles-Servick equation to calculate the ionic diffusion coefficients [34,35]:

$$
\mathrm{J}_{\mathrm{p}}=2.69 \times 10^{5} \mathrm{n}^{3 / 2} \mathrm{C}_{0} \mathrm{D}^{1 / 2} v^{1 / 2},
$$

where $\mathrm{J}_{\mathrm{p}}$ is the peak current density in unit area (working area equals to $3.5 \times 4 \mathrm{~cm}^{2}$ ), including the $\mathrm{J}_{\mathrm{pa}}$ peak current density at oxidation and $\mathrm{J}_{\mathrm{pc}}$ peak current density at reduction, $\mathrm{n}$ is the number of electrons (assumed to be 1$), \mathrm{C}_{0}(0.5 \mathrm{~mol} / \mathrm{L})$ is the concentration of the active ions in the electrolyte solution (in mol. $\mathrm{cm}^{-3}$ ), D is the diffusion coefficient of $\mathrm{Li}$ ions, and $\mathrm{v}$ is the potential scan rate $(\mathrm{mV} / \mathrm{s})$. We elucidated the electrochemical and energy storage properties of the $\mathrm{IrO}_{2} / \mathrm{ITO} /$ glass or $\mathrm{NiO} / \mathrm{ITO} /$ glass by constructing threeelectrode cells, which contained a working electrode $\left(\mathrm{IrO}_{2}\right.$ film on ITO/glass or $\mathrm{NiO}$ film on ITO/glass), a counter-electrode ( $\mathrm{Pt}$ mesh), and a reference electrode ( $\mathrm{Ag} / \mathrm{AgCl})$ in a $0.5 \mathrm{M} \mathrm{LiClO}_{4} /$ perchlorate $\left(\mathrm{LiClO}_{4} / \mathrm{PC}\right)$ solution. The electrode comparison of $\mathrm{CV}$ curves on $\mathrm{IrO}_{2} / \mathrm{ITO}$ and $\mathrm{NiO} / \mathrm{ITO}$ films with various $\mathrm{Ar} / \mathrm{O}_{2}$ gas-flow ratios $(1 / 2,1 / 2.5$, and $1 / 3$ ) was proceeded at the 25th cycle based on a linear potential sweep ranging between $-0.5 \mathrm{~V}$ and 2.0 V. The CV curves at the 25th cycle are shown in Figure $2[33,34]$. Furthermore, the diffusion of $\mathrm{Li}^{+}$ions in the electrodes was determined by calculating the diffusion coefficients (D). The $\mathrm{J}_{\mathrm{pa}}, \mathrm{J}_{\mathrm{pc}}$, and the diffusion coefficient (D) values are summarized in Table 3. In Figure 2, CV curves demonstrated the enclosed area of $\mathrm{IrO}_{2}$ films were bigger than the $\mathrm{NiO}$ at all $\mathrm{Ar} / \mathrm{O}_{2}$ gas ratios; moreover, the higher $\mathrm{Ar} / \mathrm{O}_{2}$ gas ratios led to the larger enclosed area of the two material electrode films. Note that the device showed a significant capacitive behavior and indicated the participation of more ions in the electrochemical redox process. According to Table 3 and Figure 3, sample $3\left(\mathrm{IrO} \mathrm{O}_{2}\right.$ with an $\mathrm{Ar} / \mathrm{O}_{2}$ ratio of $\left.1 / 3\right)$ presented the highest ion diffusion coefficients (D) of $1.09 \times 10^{-10} \mathrm{~cm}^{2} / \mathrm{s}$ (oxidation) $/ 1.10 \times 10^{-10} \mathrm{~cm}^{2} / \mathrm{s}$ (reduction) in the $\mathrm{IrO}_{2}$ film, and sample 6 ( $\mathrm{NiO}$ with $\mathrm{Ar} / \mathrm{O}_{2}$ ratio is 1/3) presented the highest ion diffusion coefficients (D) of $1.93 \times 10^{-11} \mathrm{~cm}^{2} / \mathrm{s}$ (oxidation) $/ 3.12 \times 10^{-11} \mathrm{~cm}^{2} / \mathrm{s}$ (reduction) in the $\mathrm{NiO}$ film. The higher diffusion coefficients represented a larger contact area and greater porosity, resulting in faster ion insertion/extraction, which was good for the transportation of Li ions. 


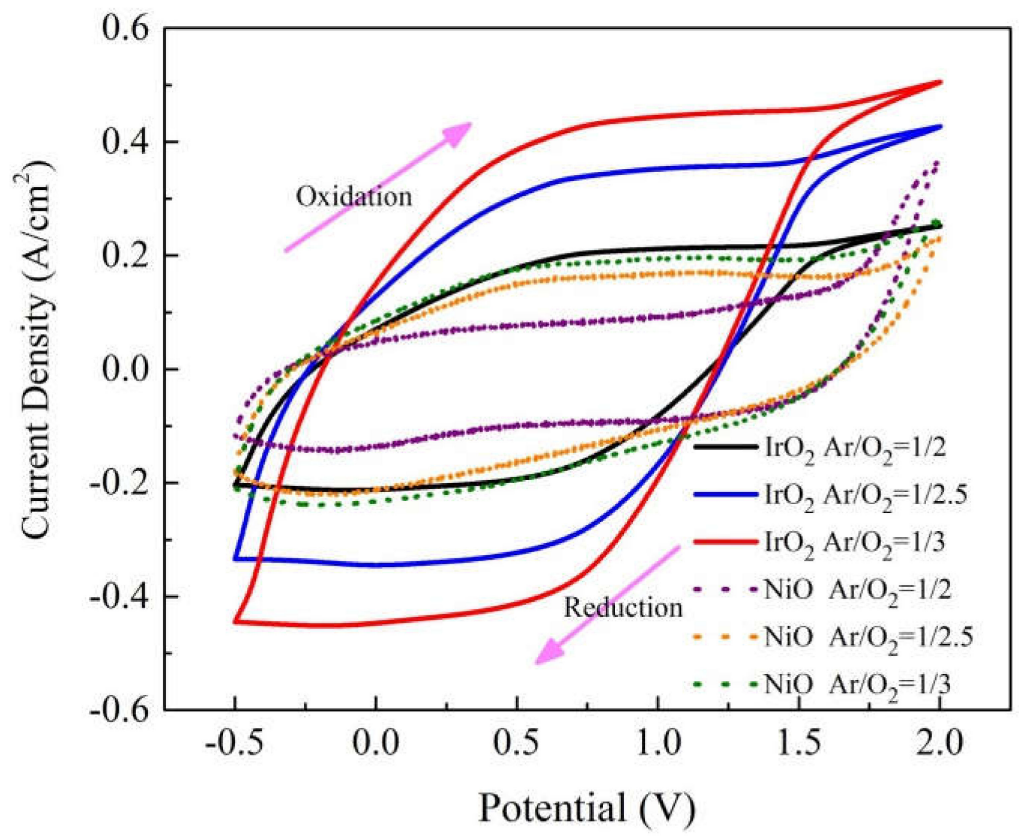

Figure 2. Comparison of 25th cycle $\mathrm{CV}$ curve of $\mathrm{IrO}_{2}$ (solid line) and $\mathrm{NiO}$ (dotted line) electrode films at a potential sweep rate of $100 \mathrm{mV} / \mathrm{s}$.

Table 3. Diffusion coefficients of $\mathrm{IrO}_{2}$ and $\mathrm{NiO}$ electrodes with various $\mathrm{Ar} / \mathrm{O}_{2}$ mixing ratios.

\begin{tabular}{ccccccc}
\hline No. & Electrode & $\begin{array}{c}\mathbf{A r} / \mathbf{O}_{\mathbf{2}} \\
(\mathbf{A r}=\mathbf{2 0} \mathbf{~ s c c m})\end{array}$ & $\begin{array}{c}\text { Anodic } \\
\text { Current } \\
\left(\mathbf{j}_{\mathbf{p a}}\right)\end{array}$ & $\begin{array}{c}\text { Cathodic } \\
\text { Current } \\
\left(\mathbf{j}_{\mathbf{p c}}\right)\end{array}$ & $\begin{array}{c}\mathbf{D} \text { for } \mathbf{j}_{\mathbf{p a}} \\
\text { Oxidation }\end{array}$ & $\begin{array}{c}\mathbf{D} \text { for } \mathbf{j}_{\mathbf{p c}} \\
\mathbf{R e d u c t i o n}\end{array}$ \\
\hline Sample 1 & $\mathrm{IrO}_{2}$ & $1 / 2$ & $2.82 \times 10^{-4}$ & $2.83 \times 10^{-4}$ & $4.40 \times 10^{-11}$ & $4.42 \times 10^{-11}$ \\
Sample 2 & $\mathrm{IrO}_{2}$ & $1 / 2.5$ & $3.53 \times 10^{-4}$ & $3.45 \times 10^{-4}$ & $6.88 \times 10^{-11}$ & $6.57 \times 10^{-11}$ \\
Sample 3 & $\mathrm{IrO}_{2}$ & $1 / 3$ & $4.44 \times 10^{-4}$ & $4.47 \times 10^{-4}$ & $1.09 \times 10^{-10}$ & $1.10 \times 10^{-10}$ \\
Sample 4 & $\mathrm{NiO}$ & $1 / 2$ & $8.70 \times 10^{-5}$ & $1.49 \times 10^{-4}$ & $4.18 \times 10^{-12}$ & $1.22 \times 10^{-11}$ \\
Sample 5 & $\mathrm{NiO}$ & $1 / 2.5$ & $1.65 \times 10^{-4}$ & $2.16 \times 10^{-4}$ & $1.50 \times 10^{-11}$ & $2.59 \times 10^{-11}$ \\
Sample 6 & $\mathrm{NiO}$ & $1 / 3$ & $1.87 \times 10^{-4}$ & $2.38 \times 10^{-4}$ & $1.93 \times 10^{-11}$ & $3.12 \times 10^{-11}$ \\
\hline
\end{tabular}

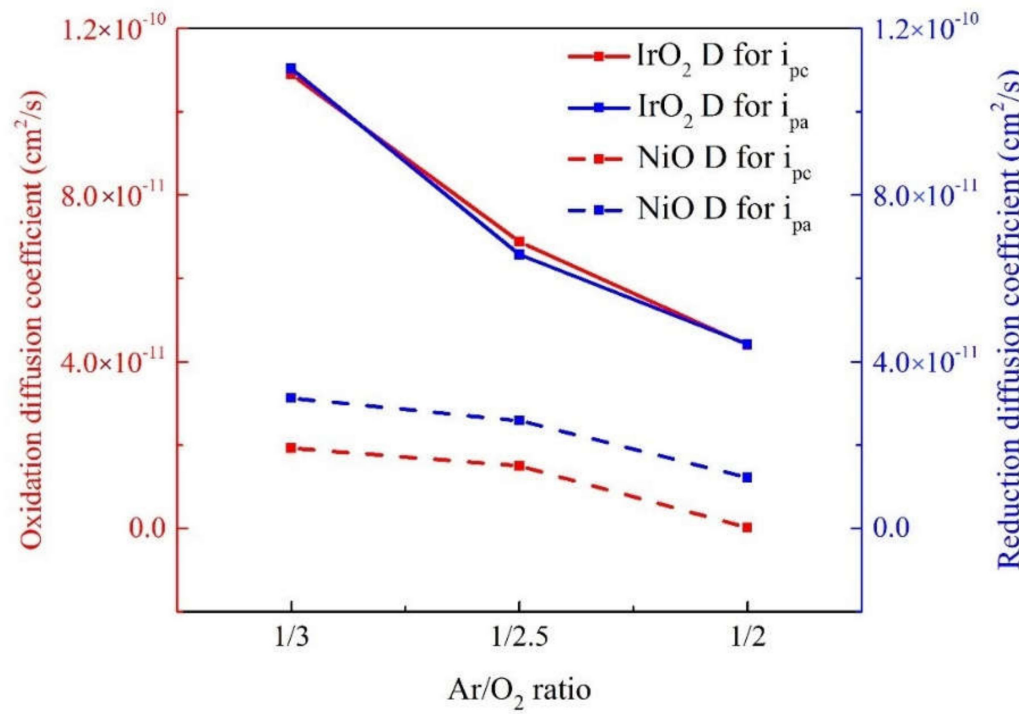

Figure 3. The comparison of diffusion coefficients of $\mathrm{IrO}_{2}$ and $\mathrm{NiO}$ electrodes with various $\mathrm{Ar} / \mathrm{O}_{2}$ mixing ratio. 


\subsection{Material Structure and Surface Morphology Analysis}

To evaluate the crystal material structure and the possible phase change during the deposition process of both the $\mathrm{IrO}_{2}$ and the $\mathrm{NiO}$ electrode films with various $\mathrm{Ar} / \mathrm{O}_{2}$ mixing ratios, the XRD diffraction patterns are shown in Figure 4; they were used to distinguish the crystalline nature and calculate the particle grain size. We acquired these structures and phase compositions by means of a comparison of the Joint Committee on Powder Diffraction Standard (JCDPS). After the subtraction of the diffraction peaks, the $\mathrm{IrO}_{2}$ electrode (JCPDS card no. 15-0870) main peak was located at a $2 \theta$ angle of $34^{\circ}$ which could be indexed as the preferential plane of (101); the NiO electrode (JCPDS card no. 47-1049) peaks located at $2 \theta \sim 37^{\circ}, 43^{\circ}$ and $63^{\circ}$ were indexed as the preferential planes of (111), (200), and (220), respectively. The (111) preferential planes were different from the preferred (200) and $(220)$ growth $[36,37]$. In Figure 4 , at various angles for the two types of electrodes, we observed that the $\mathrm{NiO}$ electrode samples were more crystalline than the $\mathrm{IrO}_{2}$ electrode ones and that the intensity of diffraction decreased with an increase in the $\mathrm{Ar} / \mathrm{O}_{2}$ mixing ratio.
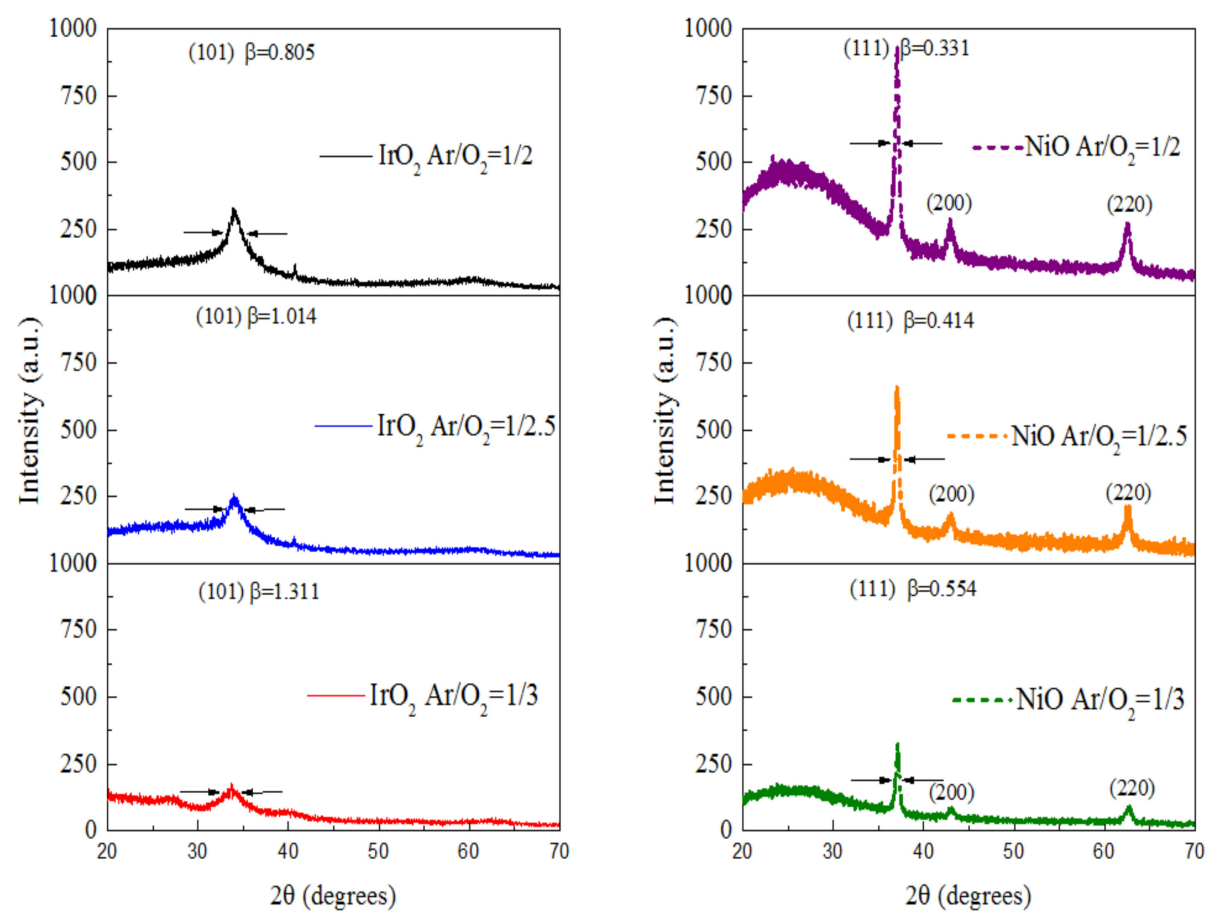

Figure 4. X-ray diffraction of $\mathrm{IrO}_{2}$ and $\mathrm{NiO}$ electrodes at various $\mathrm{Ar} / \mathrm{O}_{2}$ mixing ratio.

However, the highly crystalline structure of the material is less favorable for the insertion/extraction of $\mathrm{Li}$ ions because to the compact atom structure. Moreover, the facets (101) and (111) had more noticeable crystallinity of the $\mathrm{IrO}_{2}$ and $\mathrm{NiO}$ electrodes. The average grain size (d) for (101) of the $\mathrm{IrO}_{2}$ electrode and (111) of the $\mathrm{NiO}$ samples was calculated using Scherrer's equation [36]:

$$
\mathrm{D}=\mathrm{K} \lambda / \beta \cos \theta
$$

where $\mathrm{d}$ is the average grain size, is the dimensionless shape factor, $\lambda$ is the $\mathrm{X}$-ray wavelength, $\beta$ is the full width at half maximum (FWHM) of the X-ray diffraction peak in line broadening in radians, $\theta$ is the diffraction angle. The measured average grain sizes are presented in Table 4. 
Table 4. Average grain size of $\mathrm{IrO}_{2}$ and $\mathrm{NiO}$ electrode.

\begin{tabular}{cccccc}
\hline No. & Electrode & $\begin{array}{c}\mathbf{A r} / \mathbf{O}_{\mathbf{2}} \\
(\mathbf{s c c m})\end{array}$ & $\begin{array}{c}\mathbf{2 \theta} \\
\mathbf{( d e g )}\end{array}$ & $\begin{array}{c}\text { FWHM } \\
(\boldsymbol{\beta})\end{array}$ & $\begin{array}{c}\text { Ave Grain } \\
\text { Size (nm) }\end{array}$ \\
\hline Sample 1 & $\mathrm{IrO}_{2}$ & $1 / 2$ & $34.832^{\circ}$ & $0.805^{\circ}$ & 10.03 \\
Sample 2 & $\mathrm{IrO}_{2}$ & $1 / 2.5$ & $34.644^{\circ}$ & $1.014^{\circ}$ & 8.20 \\
Sample 3 & $\mathrm{IrO}_{2}$ & $1 / 3$ & $34.312^{\circ}$ & $1.311^{\circ}$ & 6.35 \\
Sample 4 & $\mathrm{NiO}$ & $1 / 2$ & $37.815^{\circ}$ & $0.331^{\circ}$ & 25.30 \\
Sample 5 & $\mathrm{NiO}$ & $1 / 2.5$ & $37.613^{\circ}$ & $0.414^{\circ}$ & 20.27 \\
Sample 6 & $\mathrm{NiO}$ & $1 / 3$ & $37.282^{\circ}$ & $0.554^{\circ}$ & 15.15 \\
\hline
\end{tabular}

The average grain size decreased with an increase in the $\mathrm{Ar} / \mathrm{O}_{2}$ mixing ratio of the two electrode samples. In contrast to the grain size, $\mathrm{IrO}_{2}$ electrode got the smaller size than $\mathrm{NiO}$ as the larger FWHM in Table 4. This study is to analyze surface morphology and optical and electrochromic properties $\mathrm{f}$ metal-oxide films based on various $\mathrm{Ar} / \mathrm{O}_{2}$ gas-flow ratios $[13,14,32]$. In Figure 2, we found that with increase in oxygen flow rate the current density starts decreasing during CV analysis under same voltage applied condition. The reason for this may be attributed to decrease in the number of incident CAP gas ions on the $\mathrm{NiO}$ or $\mathrm{IrO}_{2}$ with increase in oxygen flow rate. Herein, we observed that $\mathrm{IrO}_{2}$ (sample \#3) had smaller grain size of $6.35 \mathrm{~nm}$ at the $\mathrm{Ar} / \mathrm{O}_{2}$ mixing ratio of $1 / 3$ than $\mathrm{NiO}$ (sample \#6) did $(15.15 \mathrm{~nm})$. The $\mathrm{IrO}_{2}$ electrode with the smallest grain size of $6.35 \mathrm{~nm}$ demonstrated the highest diffusion coefficient, as the Li ions transferred in a less hindered film than the $\mathrm{NiO}$ electrode. The smaller grain size was desirable in Table 4 as it offered more grain boundaries, which increased the diffusion coefficient. The CV diagram and the diffusion coefficient (D) were related to the grain size, and the behavior of the electrodes was in good agreement with that in the case of a relatively small grain size [36]. The decreasing grain size was associated with the increasing enclosed area of the corresponding $\mathrm{CV}$. The enclosed area was as follows: $\mathrm{Ar} / \mathrm{O}_{2}$ gas-flow ratios $\left(1 / 2,1 / 2.5\right.$, and 1/3): (1) $\mathrm{IrO}_{2}$ at $1 / 2$ $\left(7.14 \mathrm{mC} / \mathrm{cm}^{2}\right), \mathrm{IrO}_{2}$ at $1 / 2.5\left(9.03 \mathrm{mC} / \mathrm{cm}^{2}\right), \mathrm{IrO}_{2}$ at $1 / 3\left(11.05 \mathrm{mC} / \mathrm{cm}^{2}\right)$, and $(2) \mathrm{NiO}$ at $1 / 2\left(3.24 \mathrm{mC} / \mathrm{cm}^{2}\right), \mathrm{NiO}$ at $1 / 2.5\left(5.13 \mathrm{mC} / \mathrm{cm}^{2}\right), \mathrm{NiO}$ at $1 / 3\left(6.09 \mathrm{mC} / \mathrm{cm}^{2}\right)$.

Furthermore, Figure $5 \mathrm{a}, \mathrm{c}$ show that correlate SEM surface morphology images $\mathrm{IrO}_{2}$ and $\mathrm{NiO}$ electrodes with $1 / 3$ ratio of $\mathrm{Ar} / \mathrm{O}_{2}$ at thickness $100 \mathrm{~nm}$; Figure 5b,d show the cross-sectional SEM; the electrodes specimen was prepared on coated ITO $300 \mathrm{~nm} /$ glass. Therefore, the grain size and surface morphology should be regarded as essential factors in a study on the fabrication of ECDs. Our results of $\mathrm{IrO}_{2}$ films leaded to greatly diffusion coefficient could be attributed a porous structure that it revels surface morphology of grains which is like filamentary and interconnect. In Figure 6a,c show electrode device, Figure $6 \mathrm{~b}, \mathrm{~d}$ are the grains skeleton indicated areas where adopted in Figure $6 \mathrm{a}, \mathrm{c}$ dotted line. Tthe schematics explain the Li ion path through different grain types in the $\mathrm{IrO}_{2}$ and $\mathrm{NiO}$ surface morphology of an electrochromic film. This could be attributed to the grain types of filamentary and interconnected shape with a larger inner-pore structure on the $\mathrm{IrO}_{2}$ electrode, which rendered a larger contact area and greater porosity, resulting in the Li ions having sufficient time and space to insert into/extract from the interface. In addition, the grain types provided higher diffusion coefficients. 


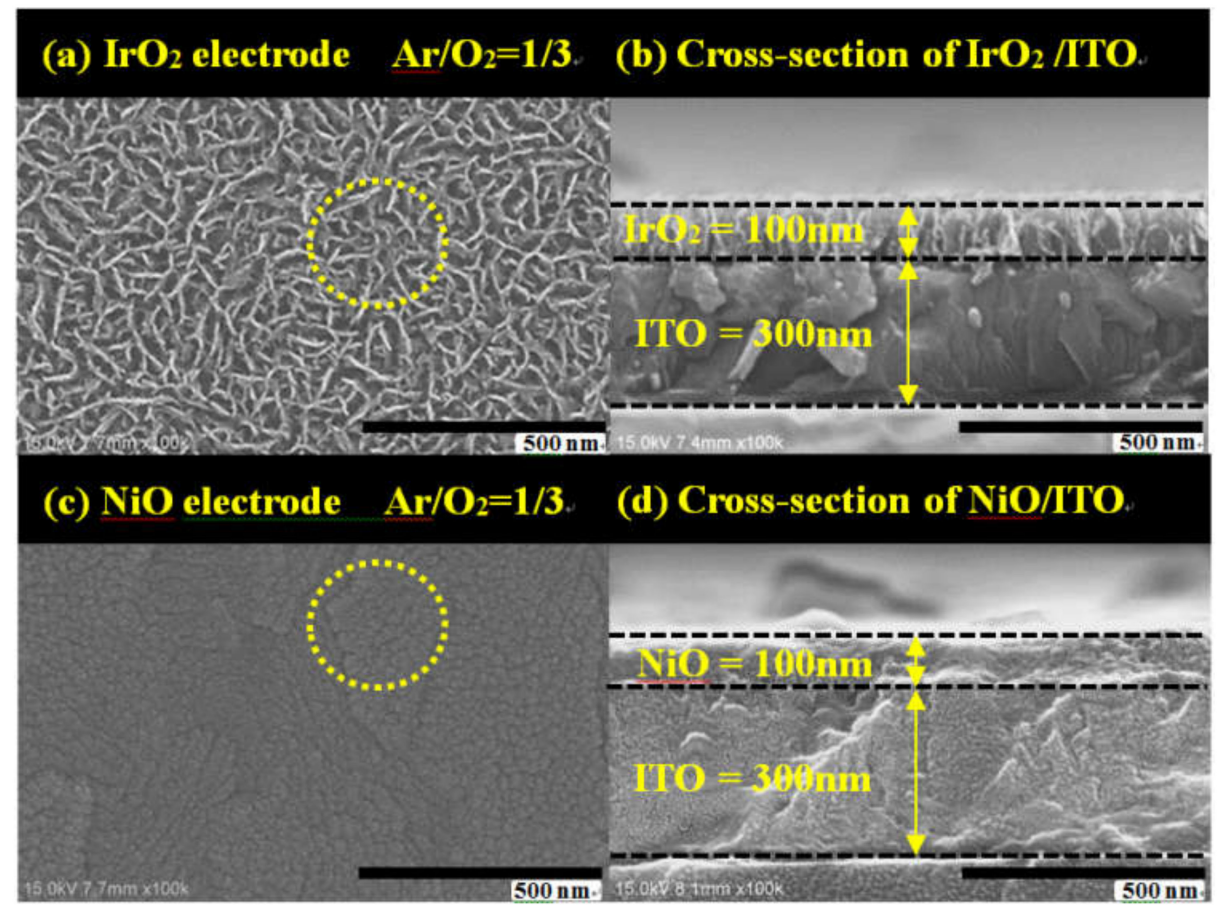

Figure 5. SEM images of surface morphology (a) $\mathrm{IrO}_{2}$ electrode with $\mathrm{Ar} / \mathrm{O}_{2}=1 / 3$ (c) $\mathrm{NiO}$ electrode with $\mathrm{Ar} / \mathrm{O}_{2}=1 / 3$; Cross-section morphology of $(\mathbf{b}) \mathrm{IrO}_{2}$ electrode with thickness $100 \mathrm{~nm}(\mathbf{d}) \mathrm{NiO}$ electrode with a thickness of $100 \mathrm{~nm}$.

(a)

(c)
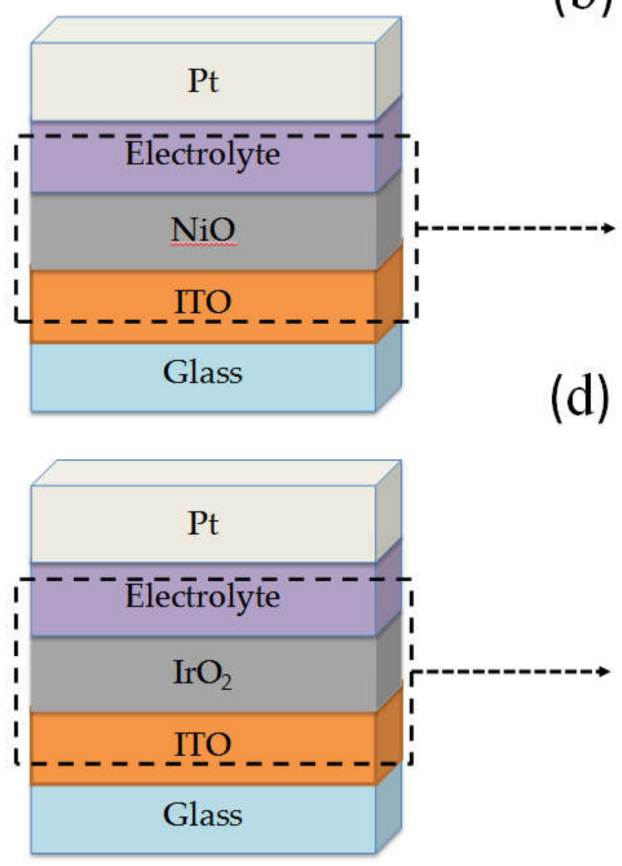

(b)

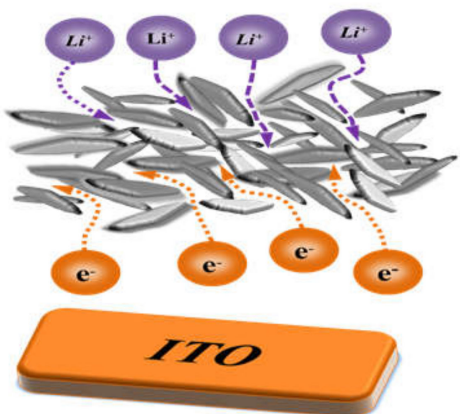

(d)

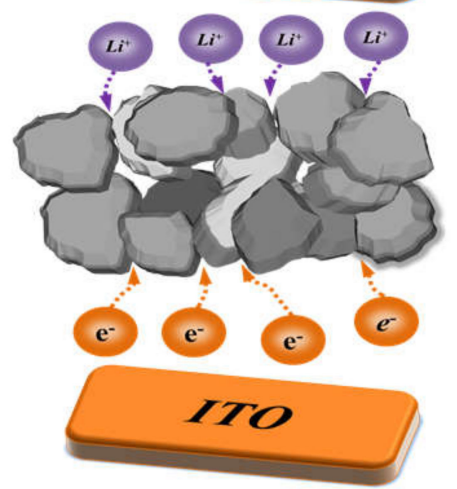

Figure 6. The schematics of Li ions path through surface morphology with different grain type (a) $\mathrm{IrO}_{2}$ electrode device (b) $\mathrm{IrO}_{2}$ electrode (c) $\mathrm{NiO}$ electrode device (d) $\mathrm{NiO}$ electrode.

\subsection{Optical Transmittance and Cycle Durability Analysis}

The optical transmittance measurement of $\mathrm{IrO}_{2} / \mathrm{ITO} /$ glass and $\mathrm{NiO} / \mathrm{ITO} /$ glass is helpful to understand the transmittance optical modulation $\left(\Delta \mathrm{T}=\mathrm{T}_{\text {bleached }}-\mathrm{T}_{\text {colored }}\right)$ at a fixed wavelength of $633 \mathrm{~nm}$, along with the switching response time and durability 
of the electrochromic devices (ECD). In Figure 7, we first elucidate the electrochemical properties of the $\mathrm{IrO}_{2} / \mathrm{ITO} /$ glass and $\mathrm{NiO} / \mathrm{ITO} /$ glass by constructing three-electrode cells, which consisted of a working electrode $\left(\mathrm{IrO}_{2}\right.$ film on ITO/glass and $\mathrm{NiO}$ film on ITO/glass), a counter-electrode (Pt mesh) and a reference electrode $(\mathrm{Ag} / \mathrm{AgCl})$ in a $0.5-\mathrm{M}$ $\mathrm{LiClO}_{4} /$ perchlorate $\left(\mathrm{LiClO}_{4} / \mathrm{PC}\right)$ solution. In Figure 7 , the optical transmittance spectra of $\mathrm{IrO}_{2} / \mathrm{ITO} /$ glass and $\mathrm{NiO} / \mathrm{ITO} /$ glass were carried with from 1.5 to $-0.3 \mathrm{~V}$ versus $\mathrm{AgCl} / \mathrm{Ag}$ with an $\mathrm{Ar} / \mathrm{O}_{2}$ ratio of $1 / 3$ at $633 \mathrm{~nm}$. In our results, $\mathrm{IrO}_{2} / \mathrm{ITO} /$ glass had a higher optical transmittance modulation, $\Delta \mathrm{T}=35 \%$ (from $\mathrm{T}_{\text {bleaching }}(65 \%)$ to $\mathrm{T}_{\text {coloring }}(30 \%)$ ), than the $\mathrm{NiO}$ electrode, $\Delta \mathrm{T}=23 \%$ (from $\mathrm{T}_{\text {bleaching }}(53 \%)$ to $\mathrm{T}_{\text {coloring }}(30 \%)$ ). Note that the modulation of the optical transmittance of the $100-\mathrm{nm}$-thick $\mathrm{IrO} \mathrm{O}_{2}$ film with an $\mathrm{Ar} / \mathrm{O}_{2}$ ratio of $1 / 3$ was higher than that of the other samples, as indicated by the larger enveloped area in the CV curve in Figures 2 and 7 show that the coloration and bleaching state of ECDs, as analyzed during a continuous potential from $-2 \mathrm{~V}$ (coloration potential, $\mathrm{Vc}$ ) to $2 \mathrm{~V}$ (bleaching potential, $\mathrm{Vb}$ ), were measured by the CA curves and the in-situ optical response of transmittance at $633 \mathrm{~nm}$. The coloration and bleaching of the switching times and speed were very important factors for the ECD system; it is defined as the time required for a $90 \%$ change in the full transmittance modulation [8]. Figure 8 presents the electrochromic performance of optical transmittance modulation at $633 \mathrm{~nm}$ after 1000 cycles. It demonstrated that $\mathrm{IrO}_{2}-\mathrm{ECD}$ (glass $/ \mathrm{ITO} / \mathrm{WO}_{3} /$ liquid electrolyte $/ \mathrm{IrO}_{2} / \mathrm{ITO} /$ glass) $\Delta \mathrm{T}_{1}=50 \%$ (from $\mathrm{T}_{\text {bleaching }}(75 \%$ ) to $\mathrm{T}_{\text {coloring }}(25 \%)$ ) was higher than that of NiO-ECD (ITO/NiO/liquid electrolyte/ $\mathrm{WO}_{3} / \mathrm{ITO}$ ) $\Delta \mathrm{T}_{2}=32 \%$. In the 1000-cycle durability analysis, the optical transmittance indicated that $\mathrm{IrO}_{2}$-ECD demonstrated excellent durability, which remained as $96 \%$ of the original state value, as the $\mathrm{IrO}_{2}$ electrode had more transferred $\mathrm{Li}$ ions and outperformed NiO-ECD ( $78 \%$ of the original value). Figure $9 \mathrm{a}, \mathrm{b}$ show the switching response time, including the bleaching and the coloration time in the middle of a long durability cycle test (@500 cycles). Figure 9a shows that in the case of $\mathrm{IrO}_{2}-\mathrm{ECD}$, the switching response time was $1.5 \mathrm{~s}$ from the colored state to the bleached state and $4.8 \mathrm{~s}$ from the bleached state to the colored one. The $\mathrm{IrO}_{2}$-ECD in Figure 9a was faster than the NiO-ECD in Figure 9b, which took $1.7 \mathrm{~s}$ to switch from the coloration state to the bleaching state and $5.5 \mathrm{~s}$ to switch from the bleaching state to the coloration one. The faster switching speed was associated with the higher diffusion coefficients and the filamentary shape of the interface in the case of the $\mathrm{IrO}_{2}$ electrode, which facilitated the transfer of the $\mathrm{Li}$ ions into/out of interface electrodes and the electrolyte. The $\mathrm{IrO}_{2}$-ECD showed higher optical transmittance modulation than NiO-ECD which was useful for promoting electrochromic application for cycle durability test. A comparison of the electrochromic and optical properties obtained in this study which was reported in previous research and presented in Table 5. 


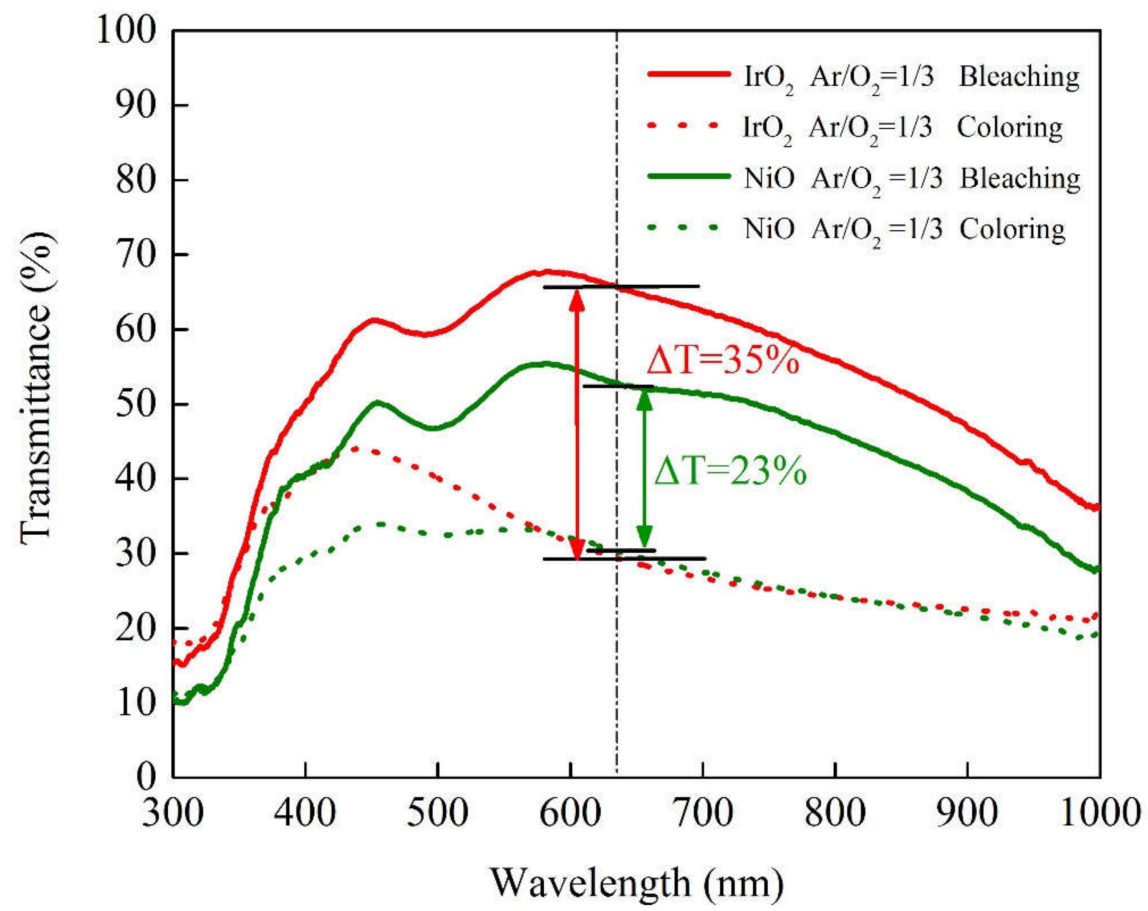

Figure 7. The optical transmittance spectra showing coloring and bleaching comparison states of the $\mathrm{IrO}_{2}$ and $\mathrm{NiO}$ electrodes with $\mathrm{Ar} / \mathrm{O}_{2}=1 / 3$ in the range from $300 \mathrm{~nm}$ to $1000 \mathrm{~nm}$.

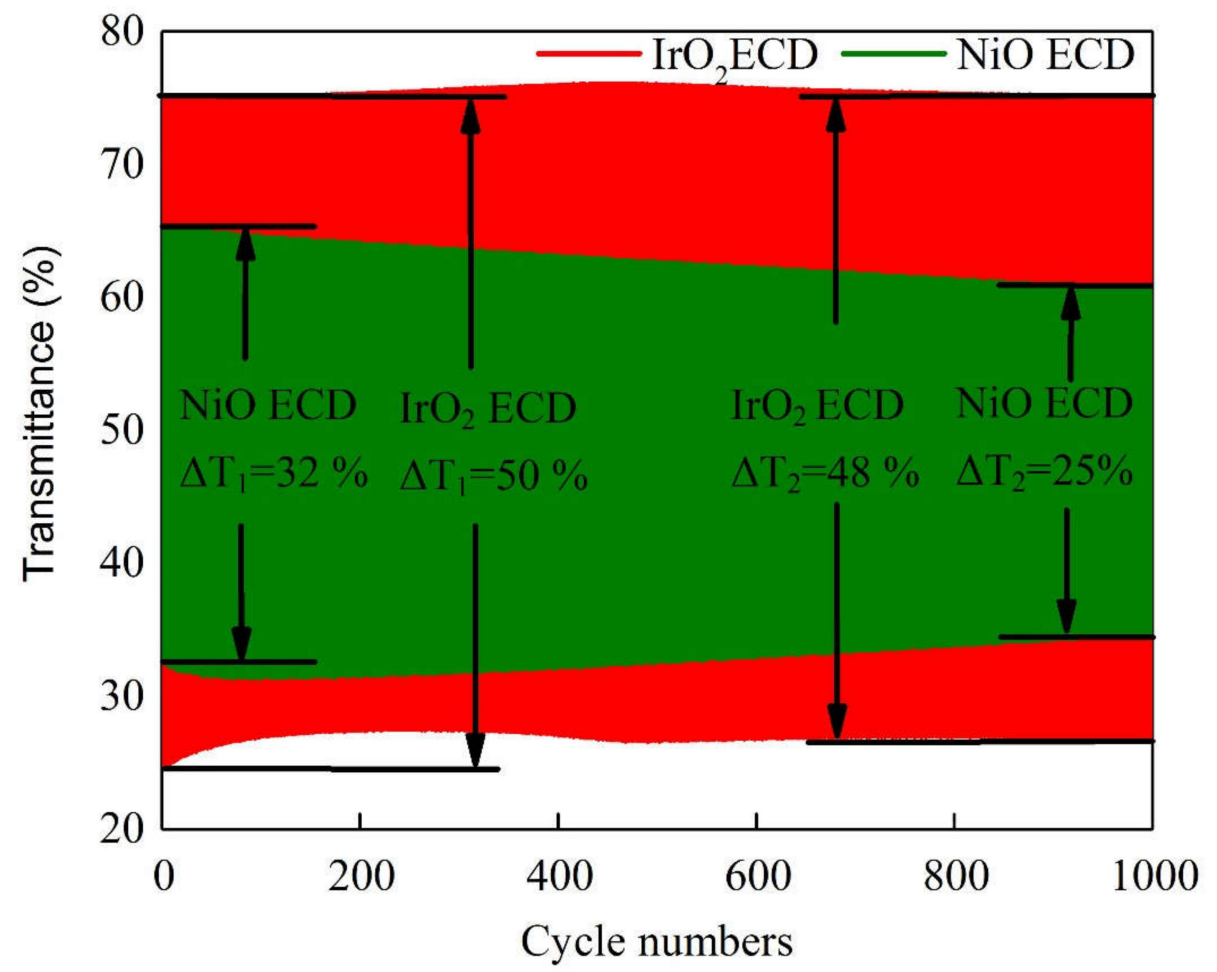

Figure 8. The comparison durability of the electrochromic device (ECD) is evaluated by optical transmittance modulation at $633 \mathrm{~nm}$ during 1000 cycles. 


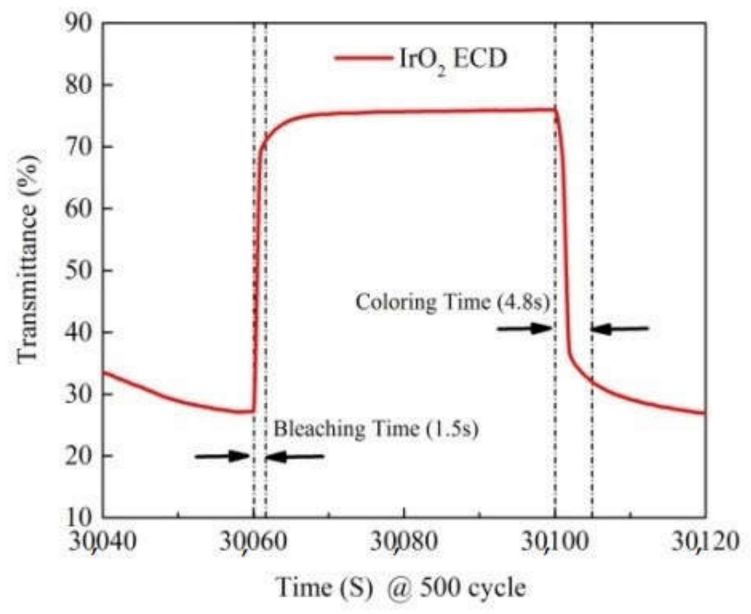

(a)

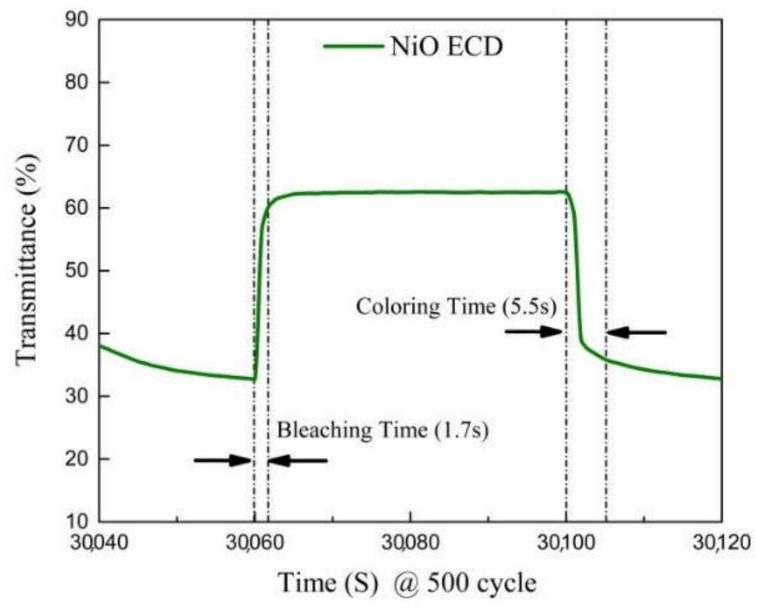

(b)

Figure 9. (a) $\mathrm{IrO}_{2}$ ECD and (b) NiO ECD: Switch response time for one single bleaching and coloring states @ 500 cycle $(30040 \rightarrow 30120 \mathrm{~s})$.

Table 5. Comparison of our results with the literature on various materials and methods $[8,10,13,37-39]$.

\begin{tabular}{cccccc}
\hline Materials/Device & Method & $\begin{array}{c}\Delta \mathbf{T} \\
\mathbf{( \% )}\end{array}$ & $\begin{array}{c}\mathbf{C E} \\
\left(\mathbf{c m}^{\mathbf{2}} / \mathbf{C}\right)\end{array}$ & $\begin{array}{c}\text { Switching Time } \\
\left(\mathbf{t}_{\mathbf{c}} / \mathbf{t}_{\mathbf{b}} \mathbf{)}\right.\end{array}$ & Ref. \\
\hline $\mathrm{WO}_{3} / \mathrm{IrO}_{2}$ & $\mathrm{CAP}$ & 50 & - & $4.8 / 1.5 \mathrm{~s}$ & This work \\
$\mathrm{WO}_{3} / \mathrm{NiO}$ & $\mathrm{CAP}$ & 46 & 90 & $3.1 / 4.6 \mathrm{~s}$ & {$[8]$} \\
$\mathrm{WO}_{3} / \mathrm{NiO}$ & $\begin{array}{c}\mathrm{DC} \\
\mathrm{Sputtering}\end{array}$ & 55 & 87 & $10 / 20 \mathrm{~s}$ & {$[37]$} \\
$\mathrm{WO}_{3} / \mathrm{PANI}$ & $\begin{array}{c}\text { Electro } \\
\text { polymerization }\end{array}$ & 37.4 & 98.4 & $9.9 / 13.6 \mathrm{~s}$ & {$[38]$} \\
$\mathrm{WO}_{3} / \mathrm{PANI}$ & $\begin{array}{c}\text { Dip-coating } \\
\mathrm{WO}_{3}\end{array}$ & 54.3 & 79.7 & $1.4 / 1.1 \mathrm{~s}$ & {$[10]$} \\
$\left(\mathrm{NH}_{4}\right)_{0} \cdot 33 \mathrm{WO}_{3}$ & $\begin{array}{c}\text { Spray } \\
\text { Hydrothermal }\end{array}$ & - & - & - & {$[13]$} \\
& & 60.9 & 60.9 & $5.7 / 4.2 \mathrm{~s}$ & {$[39]$} \\
\hline
\end{tabular}

\section{Conclusions}

In conclusion, we presented a comparison of electrodes on $\mathrm{IrO}_{2} / \mathrm{ITO}$ and $\mathrm{NiO} / \mathrm{ITO}$ films with various $\mathrm{Ar} / \mathrm{O}_{2}$ gas-flow ratios in ECDs and investigated the electrochemical, structural, and optical properties. We developed electrochromic electrodes by using the CAP technique as an alternative method to fabricate ECDs with a high deposition rate and at a low cost. We observed that the $\mathrm{IrO}_{2}$ electrode films with a filamentary surface morphology and an $\mathrm{Ar} / \mathrm{O}_{2}$ ratio of $1 / 3$ (sample 3) demonstrated the highest ion diffusion coefficients (D) of $1.09 \times 10^{-10} \mathrm{~cm}^{2} / \mathrm{s}$ (oxidation) $/ 1.10 \times 10^{-10} \mathrm{~cm}^{2} / \mathrm{s}$ (reduction) and the smallest grain size of $6.35 \mathrm{~nm}$. The electrochromic performance of $\mathrm{IrO}_{2}-\mathrm{ECD}$ (glass $/ \mathrm{ITO} / \mathrm{WO}_{3} /$ liquid electrolyte $/ \mathrm{IrO}_{2} / \mathrm{ITO} /$ glass) for the optical transmittance modulation, $\Delta \mathrm{T}=50 \%$ (from $\mathrm{T}_{\text {bleaching }}(75 \%)$ to $\mathrm{T}_{\text {coloring }}(25 \%)$ ) at $633 \mathrm{~nm}$, was higher than that of NiO-ECD, $\Delta \mathrm{T}=32 \%$, after 1000 cycles. The $\mathrm{IrO}_{2}-\mathrm{ECD}$ demonstrated excellent durability after 1000 cycles, which remained at $96 \%$ of the original value, and outperformed NiO-ECD ( $78 \%$ of the original value). We found that $\mathrm{IrO}_{2}-\mathrm{ECD}$ had a switching response time of $1.5 \mathrm{~s}$ from the coloration state to the bleaching state and $4.8 \mathrm{~s}$ from the bleaching state to the coloration one. The fast response time of the $\mathrm{IrO}_{2}$ electrode facilitated the transfer of $\mathrm{Li}$ ions into/out of the interface electrodes and the electrolyte, owing to the higher diffusion coefficients and the filamentary shape of the interface. Therefore, we concluded that $\mathrm{IrO}_{2}$ -ECD is promising for electrochromic applications to a cycle durability test, as an alternative to $\mathrm{NiO}-\mathrm{ECD}$. 
Author Contributions: The study was written by T.-F.K. and reviewed by P.-W.C.; the data collection and analysis for $\mathrm{WO}_{3}$ film/NiO film were conducted by T.-F.K.; C.-T.C. and S.-C.H. The manuscripts were prepared by K.-M.L. and H.-T.Y. All authors have read and agreed to the published version of the manuscript.

Funding: This research was funded by Division of Physics, Institute of Nuclear Energy Research (INER), Taiwan and National Taiwan University under the Excellence Improvement Program for Doctoral Students (grant number 108-2926-I-002-002-MY4), sponsored by Ministry of Science and Technology, Taiwan.

Institutional Review Board Statement: Not applicable.

Informed Consent Statement: Not applicable.

Data Availability Statement: The data presented in this study are available on request from the corresponding author. The data are not publicly available due to privacy.

Acknowledgments: This article was subsidized for English editing by National Taiwan University under the Excellence Improvement Program for Doctoral Students (grant number 108-2926-I-002002-MY4), sponsored by Ministry of Science and Technology, Taiwan. PWC would also like to acknowledge support from Division of Physics, Institute of Nuclear Energy Research, Taiwan.

Conflicts of Interest: The authors declare no conflict of interest.

\section{References}

1. Granqvist, C.G.; Arvizu, M.A.; Bayrak Pehlivan, I.; Qu, H.Y.; Wen, R.T.; Niklasson, G.A. Electrochromic materials and devices for energy efficiency and human comfort in buildings:A critical review. Electrochim. Acta 2018, 259, 1170-1182. [CrossRef]

2. Tie, S.F.; Tan, C.W. A review of energy sources and energy management system in electric vehicles. Renew. Sustain. Energy Rev. 2013, 20, 82-102. [CrossRef]

3. Sami, O.; Cedric, G.G.; Christophe, D.; Cedric, D.; Raphael, S. All inorganic thin film electrochromic device using LiPON as the ion conductor. Sol. Energy Mater. Sol. Cells 2016, 145, 2-7.

4. Cai, G.; Peter, D.; Cui, M.; Chen, J.; Wang, X.; Eh, A.L.S.; Magdassi, S.; Lee, P.S. Inkjetprinted all solid-state electrochromic devices based on $\mathrm{NiO} / \mathrm{WO}_{3}$ nanoparticle complementary electrodes. Nanoscale 2016, 8, 348-357. [CrossRef]

5. Qu, H.; Zhang, H.; Li, N.; Tong, Z.; Wang, J.; Zhao, J.; Li, Y. A rapid-response electrochromic device with significantly enhanced electrochromic performance. RSC Adv. 2015, 5, 803-806. [CrossRef]

6. Cai, G.F.; Tu, J.P.; Zhou, D.; Wang, X.L.; Gu, C.D. Growth of vertically aligned hierarchical $\mathrm{WO}_{3}$ nano-architecture arrays on transparent conducting substrates with outstandingelectrochromic performance. Sol. Energy Mater. Sol. Cells 2014, 124, 103-110. [CrossRef]

7. Li, H.; McRae, L.; Elezzabi, A.Y. Solution-processed interfacial PEDOT: PSS assemblyinto porous tungsten molybdenum oxide nanocomposite films for electrochromic applications. ACS Appl. Mater. Interfaces 2018, 10, 10520-10527. [CrossRef]

8. Chen, P.W.; Chang, C.T.; Ko, T.F.; Hsu, S.C.; Li, K.D.; Wu, J.Y. Fast response ofcomplementary electrochromic device based on $\mathrm{WO}_{3} / \mathrm{NiO}$ electrodes. Sci. Rep. 2020, 10, 8430-8442. [CrossRef] [PubMed]

9. Chang, C.C.; Chi, P.W.; Chandan, P.; Lin, C.K. Electrochemistry and Rapid ElectrochromismControl of $\mathrm{MoO}_{3} / \mathrm{V}_{2} \mathrm{O}_{5} \mathrm{Hybrid}_{\mathrm{Nano}}$ bilayers. Nat. Mater. 2019, 12, 2475. [CrossRef]

10. Wang, W.Q.; Wang, X.L.; Xia, X.H.; Yao, Z.J.; Zhong, Y.; Tu, J.P. Enhanced electrochromic and energy storage performance in mesoporous $\mathrm{WO}_{3}$ film and its application in abifunctional smart window. Nanoscale 2018, 10, 8162-8169. [CrossRef] [PubMed]

11. Zhan, C.; Yu, G.; Lu, Y.; Wang, L.; Wujcik, E.; Wei, S. Conductive polymer nanocomposites: A critical review of modern advanced devices. J. Mater. Chem. C 2017, 5, 1569. [CrossRef]

12. Heydari Gharahcheshmeh, M.; Gleason, K. Device Fabrication Based on oxidative Chemical Vapor Deposition (OCVD) Synthesis of Conducting Polymers and Related Conjugated Organic Materials. Adv. Mater. Interfaces 2019, 6, 1801564. [CrossRef]

13. Kim, H.; Choi, D.; Kim, K.; Chu, W.; Chun, D.M.; Lee, C.S. Effect of particle size andamorphous phase on the electrochromic properties of kinetically deposited $\mathrm{WO}_{3}$ films. Sol. Energy Mater. Sol. Cells 2018, 177, 44-50. [CrossRef]

14. Shien, L.; Zheng, J.; $\mathrm{Xu}, \mathrm{C}$. Enhanced electrochromic switches and tunable green fluorescencebased on terbium ion doped $\mathrm{WO}_{3}$ films. Nanoscale 2019, 11, 23049-23057. [CrossRef]

15. Yue, Y.; Li, H.; Li, K.; Wang, J.; Wang, H.; Zhang, Q.; Li, Y.; Chen, P. High-performancecomplementary electrochromic device based on $\mathrm{WO}_{3} \cdot 0.33 \mathrm{H} 2 \mathrm{O} / \mathrm{PEDOT}$ and prussian blueelectrodes. J. Phys. Chem. Solids 2017, 110, 284-289. [CrossRef]

16. Deniz, D.; Frankel, D.J.; Lab, R.J. Nanostructured tungsten and tungsten trioxide filmsprepared by glancing angle deposition. Thin Solid Films 2010, 518, 4095-4099. [CrossRef]

17. Usha, K.S.; Sivakumar, R.; Sanjeeviraja, C.; Sathe, V.; Ganesan, V.; Wang, T.Y. Improvedelectrochromic performance of a radio frequency magnetron sputtered $\mathrm{NiO}$ thin film with high optical switching speed. Thin Solid Films 2016, 6, 79668-79680.

18. Wnag, L.; Yuan, L.; Wu, X.; Hou, C.; Feng, S. Electrochromic response of pulsed laser deposition prepared $\mathrm{WO}_{3}-\mathrm{TiO}_{2}$ composite film. RSC Adv. 2014, 4, 47670-47676. [CrossRef] 
19. Liao, C.C. Lithium-driven electrochromic properties of electrodeposited nickel hydroxide electrodes. Sol. Energy Mater. Sol. Cells 2012, 99, 26-30. [CrossRef]

20. Lin, Y.S.; Wu, S.S.; Tsai, T.H. Electrochromic properties of novel atmospheric pressureplasma jet-synthesized-organotungsten oxide films for flexible electrochromic devices. Sol. Energy Mater. Sol. Cells 2010, 94, 2283-2291. [CrossRef]

21. White, C.M.; Gillaspie, D.T.; Whitney, E.; Lee, S.H.; Dillon, A.C. Flexible electrochromicdevices based on crystalline $\mathrm{WO}_{3}$ nanostructures produced with hot-wire chemical vapor deposition. Thin Solid Films 2009, 517, 3596-3599. [CrossRef]

22. Li, W.; Zhang, X.; Chen, X.; Zhao, Y.; Wang, L.; Liu, D.; Li, X.; Chen, M.; Zhao, J.; Li, Y. Preparation and performance of fast-response ITO/Li-NiO/Li- $\mathrm{WO}_{3} / \mathrm{ITO}$ all-solid-stateelectrochromic devices by evaporation method. Mater. Mater. Lett. 2020, 265, 127464-127466. [CrossRef]

23. Li, S.; Yao, Z.; Zhou, J.; Zhang, R.; Shen, H. Fabrication and characterization of $\mathrm{WO}_{3}$ thinfilms on silicon surface by thermal evaporation. Mater. Mater. 2017, 195, 213-216.

24. Kim, S.K.; Seok, H.J.; Kim, D.H.; Choi, D.H.; Nam, S.J.; Kim, S.C.; Kim, H.K. Comparisonof NiOx thin film deposited by spincoating or thermal evaporation for application as a holetransport layer of perovskite solar cells. RSC Adv. 2014, 4, 47670-47676.

25. Zhi, M.; Huang, W.; Shi, Q.; Wang, M.; Wnag, Q. Sol-gel fabrication of $\mathrm{WO}_{3} / \mathrm{RGO}$ nanocomposite film with enhanced electrochromic performance. RSC Adv. 2016, 6, 67488-67495. [CrossRef]

26. Liu, J.; Zhang, G.; Guo, K.; Guo, D.; Shi, M. Effect of the Ammonium Tungsten Precursor Solutionwith the Modification of Glycerol on Wide Band Gap $\mathrm{WO}_{3}$ Thin Film and Its Electrochromic Properties. Adv. Micromach. 2020, 11, 311. [CrossRef]

27. Xie, Z.; Zhu, Y.G.; Xu, J.; Huang, H.; Chen, D.; Shen, G. Porous $\mathrm{WO}_{3}$ with enhancedphotocatalytic and selective gas sensing properties. Cryst. Eng. Commun. 2011, 13, 6393-6398. [CrossRef]

28. Boelens, S.; Veltrop, H. Hard coatings of TiN, (TiHf) N and (TiNb) N deposited by randomand steered arc evaporation. Surf. Coat. Technol. 1987, 33, 63-71. [CrossRef]

29. Wang, C.; Shi, Z.; Li, W.; Song, X.; Jia, S.; Wang, L. IEEE Transactions on Plasma Science. IEEE 2015, 43, $2267-2274$.

30. Thornton, J.A. Influence of apparatus geometry and deposition conditions on the structure and topography of thick sputtered coatings. J. Vac. Sci. Technol. 1974, 11, 666. [CrossRef]

31. Anders, A.; Jüttner, B. Cathode mode transition in high-pressure discharge lamps at start-up Light. Res. Technol. 1990, 22, 111-115.

32. Chen, P.W.; Chang, C.T.; Ali, M.M.; Wu, J.Y.; Li, Y.C.; Chen, M.H.; Jan, D.-J.; Yuan, C.T. Tantalum oxide flm deposited by vacuum cathodic arc plasma with improved electrochromic performance. Sol. Energy Mater. Sol. Cells 2018, 182, 188-195. [CrossRef]

33. Lee, K.D. Indium-Zinc-Tin-Oxide flm prepared by DC reactive magnetron sputtering for electrochromic application. Materials 2018, 11, 2221.

34. Liu, Q.; Chen, Q.; Zhang, Q.; Xiao, Y.; Zhong, X.; Dong, G.; Terryn, H.; Baert, K.; Reiners, F.; Diao, X. In situ electrochromic efficiency of a nickel oxide thin film: Origin of electrochemical process and electrochromic degradation. J. Mater. Chem. C 2018, 6, 646. [CrossRef]

35. Pereira, S.; Goncalves, A.; Correia, N.; Pinto, J.; Pereira, L.; Martins, R.; Fortunato, E. Electrochromic behavior of NiO thin films deposited by e-beam evaporation at room temperature. Sol. Energy Mater. Sol. Cells 2014, 120, 109-115. [CrossRef]

36. Cullity, B.D.; Stock, S.R. Elements of X-ray Diffraction, 3rd ed.; Prentice Hall: Upper Saddle River, NJ, USA, 2001.

37. Zhang, J.; Tu, J.; Xia, X.; Qiao, Y.; Lu, Y. An all-solid-state electrochromic device based on $\mathrm{NiO} / \mathrm{WO}_{3}$ complementary structure and solid hybrid polyelectrolyte. Sol. Energy Mater. Sol. Cells 2009, 93, 1840-1845. [CrossRef]

38. Yang, L.; Ge, D.; Zhao, J.; Ding, Y.; Kong, X.; Li, Y. Improved electrochromic performance of ordered macroporous tungstenoxide films for IR electrochromic device. Sol. Energy Mater. Sol. Cells 2012, 100, 251-257. [CrossRef]

39. Ma, D.; Li, T.; Xu, Z.; Wang, L.; Wang, J. Electrochromic devices based on tungsten oxide films with honeycomblike nanostructures and nanoribbons array. Sol. Energy Mater. Sol. Cells 2018, 177, 51-56. [CrossRef] 